\title{
Types and chemical composition of organic matter in reforested lignite-rich mine soils
}

\author{
C. Rumpel ${ }^{a, *}, \mathrm{H}$. Knicker ${ }^{\mathrm{b}, 1}$, I. Kögel-Knabner ${ }^{\mathrm{b}, 2}$, \\ J.O. Skjemstad ${ }^{\mathrm{c}, 3}$, R.F. Hüttl ${ }^{\mathrm{a}}$
}

a Department of Soil Protection and Recultivation, Brandenburg Technical University, PO Box 10 13 44, D-03013 Cottbus, Germany

${ }^{\mathrm{b}}$ Lehrstuhl für Bodenkunde, Technische Universität München, D-85350 Freising-Weihenstephan, Germany

${ }^{c}$ CSIRO, Land and Water, Waite Road, Urrbrae, PMB 2, Glen Osmond, Adelaide, SA 5064, Australia

In the post-mining landscapes of Lusatia, forest soils develop from extremely acid, lignite-rich open cast mine spoils. The sites have been ameliorated with ash from lignite-fired power stations prior to afforestation. During stand development, incorporation of plant-derived organic matter leads to an intimate mixture with the substrate-derived lignite in the first centimetres of the soil (Ai horizon). The objective of the study was to characterise and to compare the composition of organic matter of mine soils under forest which contain substantial amounts of lignite. Therefore, the forest floor and the mineral soil ( $\mathrm{Ai}$ and $\mathrm{Cv}$ horizon) under a 20-year-old pine and a 36-year-old red oak site were analysed for elemental composition, magnetic susceptibility, chemical structure by cross-polarisation magic angle spinning (CPMAS) ${ }^{13} \mathrm{C}$ and ${ }^{15} \mathrm{~N}$ nuclear magnetic resonance (NMR) spectroscopy and lignite content by radiocarbon dating. The ${ }^{13} \mathrm{C}$ CPMAS NMR spectra of the forest floor and Ai horizon reveal signals at 56, 72, 105, 119, 130 and $150 \mathrm{ppm}$, indicating the presence of carbohydrates and lignin originating from plant material. Additionally, structures characteristic for lignite material (aromatic and aliphatic carbon) could be observed in the $\mathrm{Oh}$ and $\mathrm{Ai}$ horizons. Using radiocarbon dating, 25 to $83 \%$ of the total carbon in these horizons can be assigned to lignite. Lignite carbon may also indicate carbonaceous particles 
derived from amelioration ash as well as from lignite-derived airborne contamination, which are possible carbon sources of the forest floor and the surface soil. ${ }^{13} \mathrm{C}$ NMR and radiocarbon dating show that the subsoil ( $\mathrm{Cv}$ horizon) is dominated by carbon derived from lignite. From these results it is concluded that mine soils, rich in lignite contain up to four organic matter types, namely lignite inherent to the parent substrate, organic matter derived from decomposition of plant residues, carbonaceous particles in amelioration ash and carbonaceous particles from airborne lignite-derived contamination. ${ }^{15} \mathrm{~N}$ NMR spectroscopy revealed that most of the nitrogen of these soils is of recent biogenic origin

\section{Introduction}

In the Lusatian mining district, the organic matter of lignite-rich mine soils has several precursors due to the specific mining and rehabilitation practices used during open cast lignite mining operations. The lignite containing sediment overlying the lignite seam is removed, dumped and left for rehabilitation (Häge, 1996). The top soils are not re-used for reclamation and lignite-rich overburden material (up to $50 \mathrm{~g} / \mathrm{kg}$ Corg) is the parent substrate for soil development. In former times, long-term acidification potential from pyrite oxidation was counterbalanced by the use of alkaline ashes from industrial burning processes (Katzur and Haubold-Rosar, 1996). After application of NPK fertilizer, the sites are afforested with broad-leaved or coniferous trees. During stand development, organic matter deriving from decomposition of plant litter is incorporated into the lignite-containing surface soil.

Lignite originated as peat deposits formed in prehistorical swamps through the accumulation of plant substances whose components underwent differing degrees of chemical decomposition and polymerisation during the coalification process. Changes in structure involve a loss of proteins and carbohydrate which are most easily destroyed (Wilson et al., 1987; Bates and Hatcher, 1989). With increasing rank, the aromaticity of coal increases (Smith et al., 1993). The different formation histories of coal are responsible for the fact that coals are a very diverse set of material (Given, 1984). Compared to lignite, modern soil organic matter contains large amounts of polysaccharide material. Thus, the composition of the organic matter in lignite-containing mine soils as determined by its chemical structure may differ considerably from natural soil organic matter. In the Ai horizon, organic matter formed during the decomposition of plant material may have increased the OC content of the soil. However, lignite contributes to an unknown amount to the carbon measurements, which makes it difficult to determine carbon additions due to the decomposition of plant material. No studies have been carried out to quantify carbon derived from decomposition of plant material in these soils. The composition of the organic matter of lignite-rich mine soils remains unknown. 
In this study, we used radiocarbon dating and ${ }^{13} \mathrm{C}$ and ${ }^{15} \mathrm{~N}$ cross-polarisation magic angle spinning (CPMAS) nuclear magnetic resonance (NMR) spectroscopy, as well as magnetic susceptibility measurements and electron microscopy to characterise the organic matter of these soils. The objectives of this study were (i) to determine the contribution of lignite, lignite related carbon and decomposing plant material to the composition of organic matter of lignite rich mine soils under forest, (ii) to examine the effect of the carbon sources identified on the chemical composition of the organic matter, and (iii) to investigate the accumulation of decomposing plant litter by comparing two sites of different age.

\section{Material and methods}

\subsection{Description of the study site}

The study was carried out at rehabilitated mine sites of Lusatia, in the eastern part of the Federal Republic of Germany. The mine spoils were rehabilitated with Scots pine (Pinus sylvestris, 20 years) or with red oak (Quercus rubra, 36 years). CaO-rich ash $\left(700 \mathrm{~m}^{3} / \mathrm{ha}\right)$ from a briquette factory and a $\mathrm{NPKMg}$ fertilization ( $100 \mathrm{~kg} \mathrm{~N}, 64 \mathrm{~kg} \mathrm{P}, 174 \mathrm{~kg} \mathrm{~K}$ and $18 \mathrm{~kg} \mathrm{Mg} / \mathrm{ha}$ ) were applied to the soil at the red oak site prior to planting. For the Scots pine site, no information about the quantity of ash or fertiliser applied is available. Both soils represent an initial stage of mine soil development. The parent substrate for soil development is sandy (64-73\% sand) overburden material. After afforestation, plant-derived material accumulated on the soil surface and was incorporated into the mineral soil. Humic substances formed during the decomposition of plant litter could not be distinguished by macromorphological observation from lignite inherent to the parent substrate.

Soil samples were taken from the forest floor horizons (L, Of, Oh) and the upper $0-5 \mathrm{~cm}$ of the mineral soil of a soil profile at the red oak site, referred to as the Ai horizon. At the Scots pine site the first $0-3 \mathrm{~cm}$ of a soil profile have been sampled (Ai horizon). The subsoil ( $\mathrm{Cv}$ horizon) at $1 \mathrm{~m}$ depth was also sampled at both sites. Additionally, the soil profile under 36-year-old red oak was sampled in 2- to $10-\mathrm{cm}$ intervals for the analyses of depth functions of $\mathrm{pH}$, magnetic susceptibility, carbon and nitrogen content. Table 1 gives a description and some chemical characteristics of the investigated soils. Lignite of the parent substrate was isolated by hand-picking from the $>2 \mathrm{~mm}$ fraction of the mineral soil. Two lignite fraction present have been chosen. Lignite 1 is brown in colour and does not contain visible minerals. Lignite 2 contains mica and it is of black colour. This kind of lignite dominates in the parent substrate. Lignite-derived ash was collected from a lignite-fired power plant in the region. 
Table 1

Chemical and physical characteristics of the investigated soils

\begin{tabular}{llllllrl}
\hline Site & Horizon & $\begin{array}{l}\text { Sampling } \\
\text { depth } \\
(\mathrm{cm})\end{array}$ & $\begin{array}{l}\mathrm{pH} \\
\left(\mathrm{H}_{2} \mathrm{O}\right)\end{array}$ & $\begin{array}{l}\text { Magnetic } \\
\text { susceptibility } \\
\left(10^{-8} \mathrm{~m}^{3} / \mathrm{kg}\right)\end{array}$ & $\begin{array}{l}\text { Organic carbon } \\
\mathrm{OC} \\
(\mathrm{g} / \mathrm{kg})\end{array}$ & $\begin{array}{l}\mathrm{N} \\
(\mathrm{g} / \mathrm{kg})\end{array}$ & $\mathrm{C} / \mathrm{N}$ \\
\hline Scots pine & $\mathrm{L}$ & $3-2$ & 4.7 & 17 & 507 & 7.9 & 64 \\
20 years & Of & $2-0$ & 5.0 & 57 & 320 & 11.5 & 28 \\
& $\mathrm{Ai} 1$ & $0-1$ & 5.0 & 43 & 78 & 2.4 & 33 \\
& $\mathrm{Ai} 2$ & $1-3$ & 5.8 & 31 & 46 & 1.1 & 42 \\
& $\mathrm{Cv}$ & 100 & 3.0 & 20 & 20 & 0.5 & 40 \\
Red oak & $\mathrm{L}$ & $3-2$ & 4.6 & 15 & 462 & 6.8 & 68 \\
36 years & $\mathrm{Oh}$ & $2-0$ & 6.7 & 158 & 224 & 11.1 & 20 \\
& $\mathrm{Ai}$ & $0-5$ & 6.9 & 274 & 110 & 5.5 & 20 \\
& $\mathrm{Cv}$ & 100 & 3.2 & 14 & 37 & 0.4 & 93 \\
\hline
\end{tabular}

\section{2. pH, magnetic susceptibility, and elemental composition}

The soil samples were air-dried and the fraction $>2 \mathrm{~mm}$ was removed by dry sieving. The $\mathrm{pH}\left(\mathrm{H}_{2} \mathrm{O}\right)$ values were measured with a glass electrode in the supernatant of a $1 / 2.5(\mathrm{w} / \mathrm{v})$ soil/water suspension. Magnetic susceptibility was measured with a Forgenta ferromagnetic analyser FMA 5000. For calibration, a Kappa-Bridge KY-2 was used. $\mathrm{C}$ and $\mathrm{N}$ measurements were recorded with a Leco CNH 1000 analyser.

\subsection{Scanning electron microscopy}

Sample preparation for S.E.M. included a particle size separation after ultrasonic dispersion. The fractionation was carried out as described by Schmidt et al. (1998). The ultrasonic energy input was $150 \mathrm{~J} / \mathrm{ml}$ and had been calibrated to disperse aggregates and to preserve lignite particles. Selected particle size fractions were looked at with a Zeiss SEM (DMS 962) at $20 \mathrm{kV}$ with a working distance of $25 \mathrm{~mm}$. The samples were mounted on stoops and sputter-coated with coal.

\subsection{Radiocarbon dating}

Radiocarbon $\left({ }^{14} \mathrm{C}\right)$ age was obtained using the conventional macro-technique of liquid scintillation as described by Becker-Heidmann et al. (1988). A soil sample containing $6 \mathrm{~g}$ carbon was burned, and the carbon was subjected to benzol synthesis. After 6 weeks, the ${ }^{14} \mathrm{C}$ activity of the benzol was recorded with a scintillation spectrometer (Packard Tri Carb Model 3320). ${ }^{14} \mathrm{C}$ activities are corrected for isotopic effects. ${ }^{14} \mathrm{C}$ decay is a statistic process with a statistic 
error. The error can be minimized to a certain extent by prolonged measuring time. The measuring time was chosen to keep the error below \pm 1 pmC. Becker-Heidmann (1989) showed that the variation of replicate analysis of the same sample is smaller than the statistic error.

By radiocarbon dating, it was possible to quantify the lignite content of the sample because lignite carbon does not show ${ }^{14} \mathrm{C}$ activity (dead carbon). The amount present in the sample can be calculated using the following relationship:

$$
x=\left[1-\exp \left(-\left(t_{\mathrm{r}}-t\right) \times \ln 2 / T\right)\right] \times 100
$$

In this equation, $t_{\mathrm{r}}$ is the ${ }^{14} \mathrm{C}$ age (Stuiver and Polach, 1977), $t$ the ${ }^{14} \mathrm{C}$ age of the soil, and $T$ the Libby half life of ${ }^{14} \mathrm{C}$, i.e., 5568 years (Libby, 1969). Assuming that the sample contains a mixture of recently formed soil organic matter derived from plant litter, and dead carbon (carbon without ${ }^{14} \mathrm{C}$ activity) from lignite, $t$ equals 0 . The amount of lignite $\mathrm{C}$ present in the sample is obtained as a percentage of the total organic carbon. The determination of the lignite content with the radiocarbon age is an approximation. Exact lignite content can be obtained by correcting the measured ${ }^{14} \mathrm{C}$ activity for the elevated ${ }^{14} \mathrm{C}$ activity in recent plant material. The ${ }^{14} \mathrm{C}$ activity in the humic material at our site increased due to the nuclear testing back in the 1960s. The correction of the measured values was carried out assuming that the recently formed humic material has an activity of $115 \%$ modern carbon with regards to the standard.

\section{5. ${ }^{13}$ C CPMAS NMR analysis}

The solid-state ${ }^{13} \mathrm{C}$ NMR spectra were obtained on a Bruker MSL-100 NMR spectrometer at a frequency of $25.2 \mathrm{MHz}$. The cross-polarisation technique with magic angle spinning (CPMAS) was applied (Schaefer and Stejskal, 1976) with a spinning speed of $4-5 \mathrm{kHz}$. The ${ }^{13} \mathrm{C}$ chemical shifts were referenced to external tetramethylsilane. A contact time of $1 \mathrm{~ms}$ was used. Pulse delays between 250 and $350 \mathrm{~ms}$ were chosen. The solid-state CPMAS ${ }^{15} \mathrm{~N}$ NMR spectra were obtained on a Bruker MSL-300 NMR spectrometer at a frequency of $30.4 \mathrm{MHz}$. The chemical shifts are given relative to the nitromethane scale. A contact time of $1 \mathrm{~ms}$ with a pulse delay of 90 ms (Knicker et al., 1995) was used. A more detailed description of the CPMAS NMR technique can be obtained from Knicker and Nanny (1997).

NMR analyses were carried out after treatment with $10 \% \mathrm{HF}$ of the soil as described by Schmidt et al. (1997). HF-treatment of mineral soils leads to an enrichment in organic material by efficient removal of the mineral matrix including paramagnetic compounds. For quantification, the solid-state ${ }^{13} \mathrm{C}$ NMR spectra were integrated using the integration routine of the spectrometer. The chemical shift regions $0-45 \mathrm{ppm}, 45-110 \mathrm{ppm}, 110-160 \mathrm{ppm}$ and 160-220 ppm were assigned to alkyl-C, O-alkyl-C, aromatic $\mathrm{C}$ and carboxylic-C, respec- 
tively (Wilson, 1987). The variation of integration data of signals due to the treatment of a well-resolved FID (fourier transformation, phasing and baseline correction) is not more than 5\% (Knicker, 1993).

\section{Results and discussion}

\section{1. $p H$ and magnetic susceptibility}

$\mathrm{pH}$ values range from 7.4 in the surface soil to 3.3 in $1 \mathrm{~m}$ depth (Table 2). The high acidity in $1 \mathrm{~m}$ depth is caused by chemical weathering of ferric sulphides (pyrite and marcasite). The process generates sulphuric acid which leads, if not neutralised, to extremely low $\mathrm{pH}$ values. Site amelioration using lignite ash increased $\mathrm{pH}$ values in the horizon of amelioration $(0-13 \mathrm{~cm})$. Beneath this depth, $\mathrm{pH}$ drops to very low values $(<4.0)$. Amelioration activities can be monitored using magnetic susceptibility measurements because ash from lignite-fired power stations shows strong magnetic properties (up to $534 \times 10^{-8}$ $\mathrm{m}^{3} / \mathrm{kg}$, Table 3). Magnetic susceptibility values of up to $373 \times 10^{-8} \mathrm{~m}^{3} / \mathrm{kg}$ were found in the upper part of the mineral soil. The values decreased with depth to $10 \times 10^{-8} \mathrm{~m}^{3} / \mathrm{kg}$. The decrease of magnetic susceptibility with increasing depth in the mineral soil correlates with a decrease of $\mathrm{pH}\left(r^{2}=0.86\right)$ (Tables 1 and 2). Differences in $\mathrm{pH}$ and magnetic susceptibility between the two sites (Table 1) may be explained by the high variability of lignite-derived ashes. Unfortunately, no information could be obtained about the chemical composition of the ashes used for amelioration purposes. In the forest floor of the investigated sites, magnetic susceptibility values up to $158 \times 10^{-8} \mathrm{~m}^{3} / \mathrm{kg}$ were

Table 2

Depth functions of $\mathrm{pH}$, magnetic susceptibility, carbon and nitrogen contents in the soil profile under 36-year-old red oak

\begin{tabular}{llllll}
\hline $\begin{array}{l}\text { Depth } \\
(\mathrm{cm})\end{array}$ & $\begin{array}{l}\mathrm{pH} \\
\left(\mathrm{H}_{2} \mathrm{O}\right)\end{array}$ & $\begin{array}{l}\text { Magnetic susceptibility } \\
\left(10^{-8} \mathrm{~cm}^{3} / \mathrm{kg}\right)\end{array}$ & $\begin{array}{l}\text { Carbon } \\
(\mathrm{g} / \mathrm{kg})\end{array}$ & $\begin{array}{l}\text { Nitrogen } \\
(\mathrm{g} / \mathrm{kg})\end{array}$ & $\mathrm{C} / \mathrm{N}$ \\
\hline $0-2$ & 5.6 & 118 & 65 & 1.8 & 36 \\
$2-4$ & 6.9 & 361 & 102 & 1.9 & 53 \\
$4-8$ & 7.4 & 373 & 93 & 1.6 & 58 \\
$8-10$ & 6.4 & 135 & 66 & 1.2 & 55 \\
$10-12$ & 4.6 & 18 & 28 & 0.8 & 37 \\
$12-14$ & 4.4 & 17 & 37 & 0.6 & 58 \\
$14-20$ & 3.9 & 11 & 47 & 0.9 & 53 \\
$20-30$ & 3.7 & 10 & 31 & 0.6 & 52 \\
$30-40$ & 3.5 & 10 & 24 & 0.4 & 62 \\
$40-50$ & 3.6 & 11 & 31 & 0.6 & 46 \\
$50-100$ & 3.3 & 10 & 20 & 0.4 & 48 \\
\hline
\end{tabular}




\section{Table 3}

Properties of lignite and lignite derived ashes from an energy producing factory

\begin{tabular}{lllrll}
\hline & $\begin{array}{l}\text { Carbon } \\
(\mathrm{g} / \mathrm{kg})\end{array}$ & $\begin{array}{l}\text { Nitrogen } \\
(\mathrm{g} / \mathrm{kg})\end{array}$ & $\mathrm{C} / \mathrm{N}$ & $\begin{array}{l}\mathrm{pH} \\
\left(\mathrm{H}_{2} \mathrm{O}\right)\end{array}$ & $\begin{array}{l}\text { Magnetic susceptibility } \\
\left(10^{-8} \mathrm{~m}^{3} / \mathrm{kg}\right)\end{array}$ \\
\hline Lignite 1 & 492 & 6.1 & 43 & n.d. & n.d. \\
Lignite 2 & 136 & 3.2 & 47 & n.d. & n.d. \\
Filter ash $^{\mathrm{a}}$ & 130 & 1 & 130 & 12.2 & 255 \\
${\text { Power station } \mathrm{ash}^{\mathrm{b}}}_{\text {Airborne contamination }}$ & 234 & 1.6 & 146 & 9.6 & 534 \\
& 325 & 3.9 & 81 & 6.3 & 229 \\
\hline
\end{tabular}

${ }^{\mathrm{a}}$ Ash, which is recovered from the air filter.

${ }^{\mathrm{b}} \mathrm{Ash}$, which is recovered during the cleaning process of the power station.

recorded. They were unusually high in comparison to the plant litter layers (15 and $\left.17 \times 10^{-8} \mathrm{~m}^{3} / \mathrm{kg}\right)($ Table 1$)$.

Raask (1984) reported that magnetic particles in lignite ash consist of magnetic iron and slag. They are formed during the combustion process by the oxidation of pyrite to magnetite (Locke and Bertine, 1986). Therefore, magnetic susceptibility measurements have been used as an indication of addition of fossil fuel combustion products (Beckwith et al., 1986). Magnetic susceptibility measurements are also suitable for the detection of fly ash contamination in industrial areas (Querol et al., 1993; Schädlich et al., 1995). Dearing et al. (1995), studying the O horizons under oak and Corsican pine in the UK examined a 60-year-old pine stand. They concluded that the magnetic minerals present are originating from industrial processes. These findings are confirmed by Strzyszcz (1993), who stated that in forest soils, high magnetic susceptibility due to industrial emissions is observed mainly in the forest floor, especially the $\mathrm{Of} / \mathrm{Oh}$ horizons. High magnetic susceptibility of the forest floor (Of and $\mathrm{Oh}$ horizon) of Lusatian mine soils indicate that fly ash particles and airborne lignite dust accumulated on the soil surface (Rumpel et al., 1998). Tremendous amounts of these emissions had been released until the beginning of the 1990s, when energy was mainly generated by lignite combustion (Schmidt et al., 1996).

Our data indicate that magnetic susceptibility measurements are suitable to follow the input of fossil combustion products into the soil. Lignite ash input into the mine soils occurred during site amelioration and increased magnetic susceptibility as well as the $\mathrm{pH}$ values. Additionally, airborne lignite-derived contamination could be traced by increased magnetic susceptibility values of the Of and Oh horizon in comparison with the litter layer.

\subsection{Carbon and nitrogen content of lignite-derived material and of the soil}

Carbon and nitrogen content of the Lusatian lignite and lignite-derived ash are listed in Table 3 . The data show that carbon content of lignite can range between 136 and $492 \mathrm{~g} / \mathrm{kg}$ and nitrogen content between 3.2-6.1 g/kg. 
Lusatian lignite represents one of the earliest stages of coalification with moderate $\mathrm{C} / \mathrm{N}$ ratios (between 40 and 50). Its presence in the overburden material generates carbon contents as high as $37 \mathrm{~g} / \mathrm{kg}$ (Table $1, \mathrm{Cv}$-horizon). Due to the inefficient combustion process in power plants and/or briquette factories, the organic carbon content of Lusatian ashes used during site amelioration may be as high as $234 \mathrm{~g} / \mathrm{kg}$ (Table 3). The actual carbon content of the ash depends on its origin within the power plant. $\mathrm{C} / \mathrm{N}$ ratios of ash amount to high values (130-146). Airborne lignite-derived contamination, which was transported and deposited in large areas, is also characterised by its high carbon content (325 g/kg, Table 3). In the soil profile under 36-year-old red oak, organic carbon (OC) concentrations of $102-20 \mathrm{~g} / \mathrm{kg}$ were recorded down to $100 \mathrm{~cm}$ (Table 2). The $\mathrm{C} / \mathrm{N}$ ratio of the mineral soil varies within a wide range (36-62, Table 2). Replicated field sampling $(n=24-25)$ at the Scots pine site showed that the carbon content of the mineral soil shows a variation of up to $53 \%$ (Table 4).

In mine soils that develop on lignite free substrate, accumulation of organic matter formed during decomposition of plant material and decrease of the $\mathrm{C} / \mathrm{N}$ ratio with soil age was recorded (e.g., Gonzales-Sanregorio et al., 1991; Gil-Sotres et al., 1992). These observations are contrasting to the data recorded for Lusatian mine soils, where the total OC content seems to be more related to substrate inherent lignite. The carbon content and $\mathrm{C} / \mathrm{N}$-values of the $\mathrm{Cv}$ horizon may represent the lignite containing parent substrate. In the Ai horizon, usually carbon increase is solely related to the input of plant material (Roberts et al., 1988). In Lusatian mine soils, carbon from amelioration ash or airborne lignitederived contamination, which had been generated during burning of lignite (Goldberg, 1985; Rose, 1996), may have contributed to the carbon content of the Ai horizons. Thermal alteration of organic material leads to the formation of carbonaceous particles and elemental carbon, which may be possible contributors to highly aromatic humic substances in soil (Haumeier and Zech, 1995). Consequently, lignite-derived carbon additions may contribute to and interact with the formation of humic substances. Natural humic substances formed during the decomposition of plant litter are present in mixture with organic matter related to lignite. It is hardly possible to differentiate the organic matter types in the upper few centimetres of the soil by carbon and nitrogen analysis.

Table 4

Statistics of carbon analysis after replicated field sampling of the Scots pine site

\begin{tabular}{lllll}
\hline $\begin{array}{l}\text { Sampling depth } \\
(\mathrm{cm})\end{array}$ & No. of samples & $\begin{array}{l}\text { Average } \\
(\mathrm{mg} \mathrm{C} / \mathrm{g})\end{array}$ & Standard deviation & $\begin{array}{l}\text { Coefficient of variance } \\
(\%)\end{array}$ \\
\hline $0-30$ & 25 & 40 & 14 & 35 \\
$30-60$ & 24 & 28 & 15 & 53 \\
$>70$ & 24 & 30 & 13 & 42 \\
\hline
\end{tabular}




\subsection{Scanning electron microscopy (SEM)}

In the Oh horizon of the 36-year-old red oak site, particles resulting from combustion (spheroidal carbonaceous particles and inorganic ash spheres) are observed in high amounts in the 63 to $20 \mu \mathrm{m}$ fraction (Plate 1). They indicate that airborne fly ash, soot and lignite dust are found mainly in these fractions. In the sand fraction (200-63 $\mu \mathrm{m})$ of the Ai horizon (Plate 2), different mineral and organic particles are present. When the overburden was dumped, this horizon only consisted of quartz, silica and lignite. During ash amelioration, inorganic spheres and carbonaceous particles of industrial origin were added. Particles from airborne lignite-derived contamination may have been incorporated into the horizon. Schmidt et al. (1996) and Rumpel et al. (1998), assessing the impact of brown coal emissions on a soil and its size fractions, observed airborne lignite-derived contamination to occur mainly in the coarser size fractions ( $>6.3 \mu \mathrm{m}$ ). Electron microscopy indicates that carbonaceous and mineral particles of lignite-derived ash, as well as lignite dust, are important constituents of the investigated soils.

\subsection{Radiocarbon dating}

Radiocarbon age for the Ai horizon of the Scots pine and red oak site ranges from $4310 \pm 60$ years BP to $12970 \pm 130$ years BP (Table 5). The apparent age

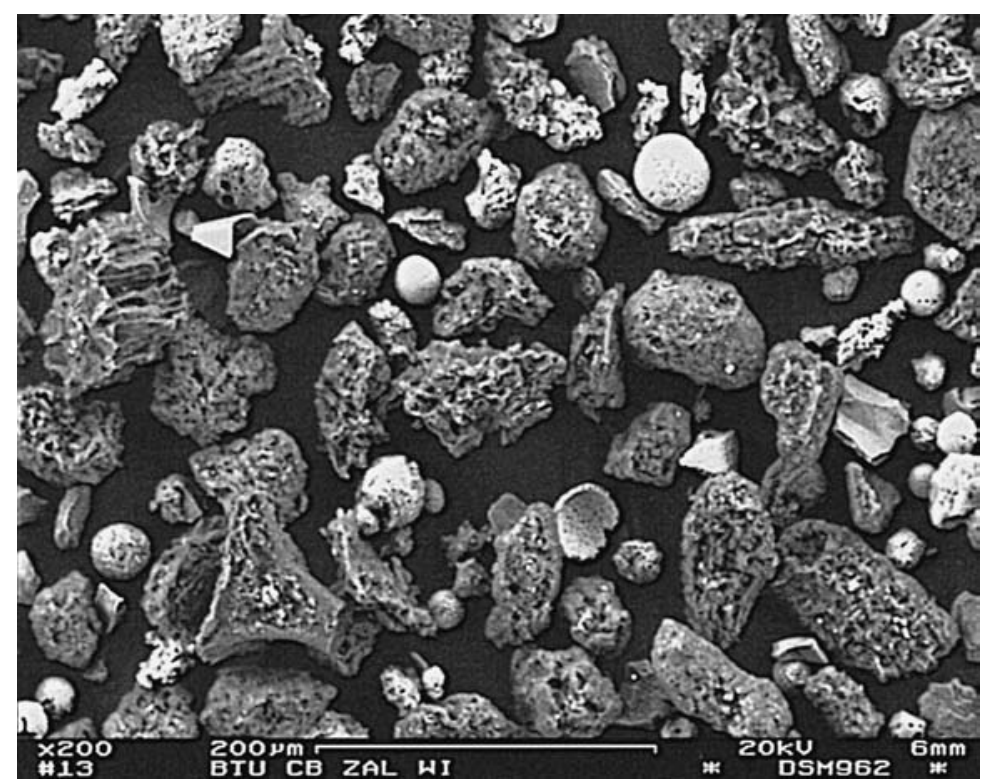

Plate 1. SEM photograph of the 60-20 $\mu \mathrm{m}$ fraction of the Oh horizon sampled in the soil profile under 36 year old red oak. 


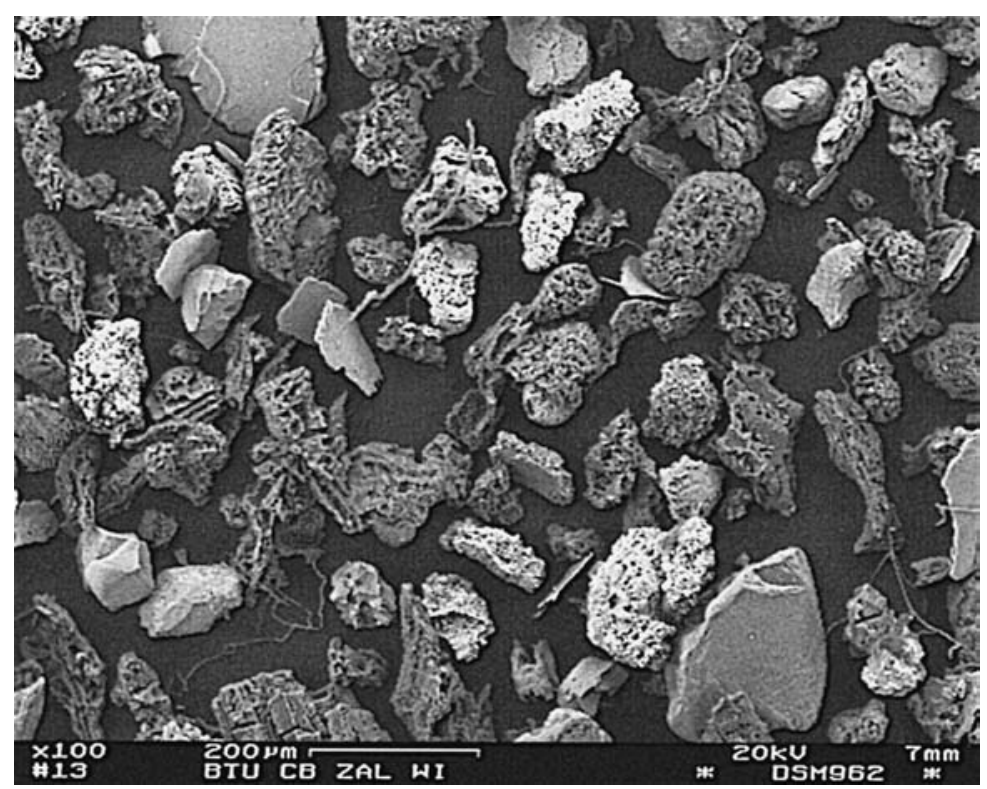

Plate 2. SEM photograph of the 200-63 $\mu \mathrm{m}$ fraction of the Ai horizon sampled in the soil profile under 36 year old red oak.

of the soils is much older than expected for the organic matter derived from accumulation of decomposing plant material. For soil organic matter, ${ }^{14} \mathrm{C}$ ages of more than 5000 years BP are not common (Becker-Heidmann et al., 1988). The extreme values detected by carbon dating are due to the contribution of dead carbon derived from the lignite present in the parent substrate for soil development, carbonaceous particles from lignite-derived ash and/or lignite dust. In $1 \mathrm{~m}$ depth, $96 \%$ of the total carbon originates from lignite. The $4 \%$ recently fixed carbon may originate from root litter. Rooting depth at this site is $120 \mathrm{~cm}$. Another explanation is translocation of dissolved organic matter of recent origin. In the Ai horizon, mixing of dead carbon (lignite) and newly formed organic matter occurred on both sites. The amount of lignite in the Ai

Table 5

${ }^{14} \mathrm{C}$ ages and calculated amount of lignite present in selected horizons at the study sites

\begin{tabular}{llclc}
\hline Site & Horizon & $\begin{array}{l}{ }^{14} \mathrm{C} \text { age } \\
(\text { years BP })\end{array}$ & $\begin{array}{l}\text { Lignite content } \\
(\% \text { of total OC) }\end{array}$ & $\begin{array}{l}\text { Recent C content } \\
(\mathrm{mg} / \mathrm{g})\end{array}$ \\
\hline 36-year-old Red oak & Oh (forest floor) & $1145 \pm 45$ & $25 \pm 0.6$ & 168.0 \\
& Ai $(0-5 \mathrm{~cm})$ & $4310 \pm 60$ & $49 \pm 0.7$ & 56.1 \\
& Cv $(1 \mathrm{~m})$ & $25640 \pm 520$ & $96 \pm 6.0$ & 0.1 \\
20-year-old Scots pine & Ai1 $(0-1 \mathrm{~cm})$ & $8270 \pm 80$ & $69 \pm 0.9$ & 24.4 \\
& Ai2 $(1-3 \mathrm{~cm})$ & $12970 \pm 130$ & $83 \pm 1.6$ & 7.8 \\
\hline
\end{tabular}


horizon represents $49 \%$ at the 36-year-old red oak site and 69 to $83 \%$ at the 20 -year-old pine site. The data normalised to the total organic carbon content $(110 \mathrm{~g} / \mathrm{kg}$ in the Ai horizon of the oak site and 46 to $78 \mathrm{~g} / \mathrm{kg}$ in the Ai horizon of the pine site, Table 1) indicate that the accumulation of organic matter formed during decomposition of plant material is higher at the red oak site $(56 \mathrm{~g} / \mathrm{kg})$ in comparison to the Ai horizon of the pine site ( 24 and $8 \mathrm{~g} / \mathrm{kg}$ ) (Table 5). The red oak stand is older and thus may have accumulated a higher amount of recent carbon. Second, higher biological activity under the broad-leaved trees might have led to more intensive mixing of organic material from decomposing litter in the mineral soil.

In the Oh horizon at the red oak site, $25 \%$ of the total OC content is dead carbon. Fly ash contamination was recognised in the forest floor of this site by magnetic susceptibility measurements, as well as electron microscopy. Thus, carbonaceous particles from airborne contamination may partly explain this value. At the red oak site epigenic and endogenic earthworm species are present. Mixing between the forest floor and the mineral soil may occur leading to high radiocarbon age of the forest floor horizon (Oh).

\section{5. ${ }^{13}$ C NMR spectra}

In a solid state ${ }^{13} \mathrm{C}$ NMR experiment of coal and related materials the efficiency of magnetisation transfer is dependent on the ${ }^{1} \mathrm{H}-{ }^{13} \mathrm{C}$ dipole-dipole interactions (Packer et al., 1983). Carbon nuclei, which are not in close proximity of protons may not undergo cross polarisation and therefore could not be 'seen' in a CP experiment by the NMR technique (Snape et al., 1989). For samples that contain significant amounts of carbon isolated from protons with a highly aromatic structure, CPMAS ${ }^{13} \mathrm{C}$ NMR may not give quantitative data (Skjemstad et al., 1997). Aromaticity of coal samples increases with increasing degree of coalification (Stach et al., 1982). Lignite is one of the earliest stages of coalification, and thus aromaticity is low. Hatcher (1988) employed contact times of $1 \mathrm{~ms}$ for CPMAS of lignite samples and suggested that the spectra are 'as quantitative as can be obtained'. Moreover, it is essential to optimise recycle times to allow for complete relaxation (Knicker and Nanny, 1997). Relaxation time of a subsoil sample containing 100\% lignite was determined to be $8 \mathrm{~ms}$ for the signals at $169 \mathrm{ppm}$ and $124 \mathrm{ppm}$, and $15 \mathrm{~ms}$ for the signals at $73 \mathrm{ppm}$ and 32 ppm. Thus, the experimental set-up chosen should be adequate to obtain comparable spectra for lignite and soil organic matter.

Spectra of lignite which was handpicked from the $>2 \mathrm{~mm}$ fraction of the soil and lignite ash sampled in a power station are shown in Fig. 1. The two lignite samples differed in carbon content (Table 3). Two distinct peaks in the chemical shift regions $0-50 \mathrm{ppm}$ and $110-160 \mathrm{ppm}$ can be observed in the spectra of both samples, representing aliphatic and aromatic carbon species. Additionally, lignite 1 shows a signal at $72 \mathrm{ppm}$, which indicates together with 


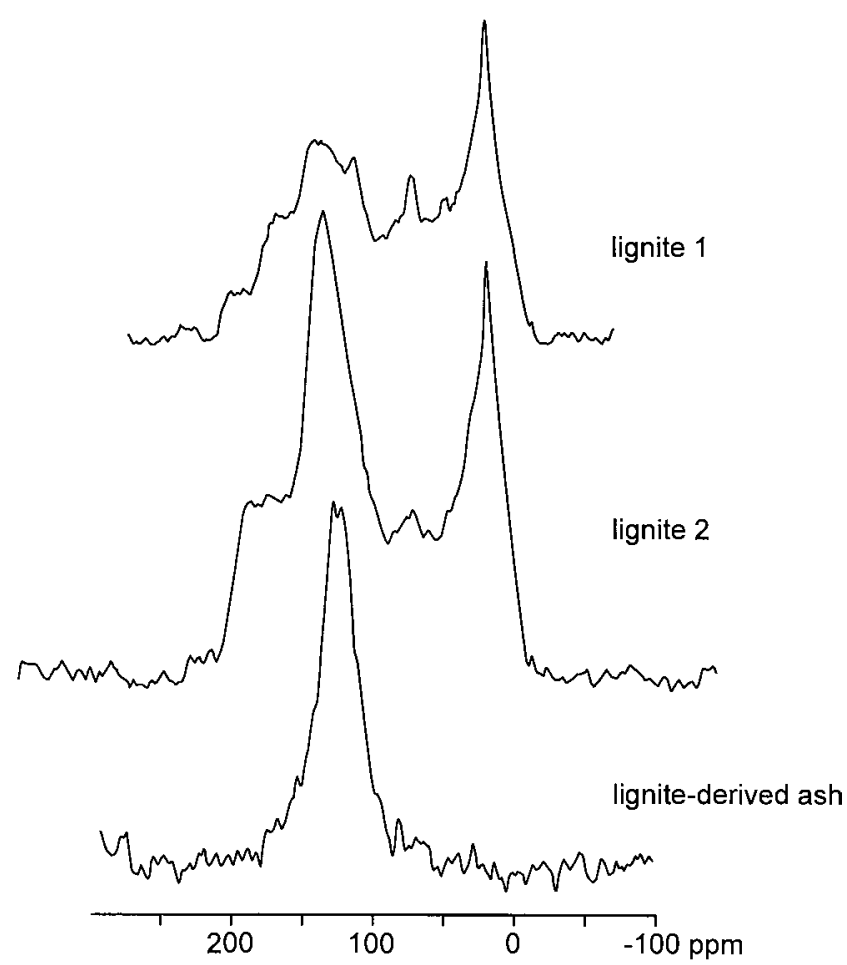

Fig. $1 .{ }^{13} \mathrm{C}$ CPMAS NMR spectra of lignite recovered from the $>2 \mathrm{~mm}$ fraction of the mineral soil under 36-year-old red oak and of lignite-derived ash from a lignite-fired power station.

the peak at $105 \mathrm{ppm}$ the presence of a small fraction of polysaccharides. Further, the signals at 56 and $150 \mathrm{ppm}$ are characteristic of lignin. Lignite 2 does not show the presence of these plant litter compounds. Also, this lignite sample is more aromatic in nature. A spectrum of ash from a lignite-fired power station shows that the carbonaceous particles of ash are highly aromatic. The differences between the two lignite samples can be explained by the small-scale differences of the formation environment. Polysaccharides and lignin have been found to be able to survive the early coalification (Bates and Hatcher, 1989). This may have been the case for lignite 1 . The spectrum of lignite 2 indicates that geochemical conditions (pressure and temperature) generated a higher degree of coalification. Burning of lignite leads to further loss of the aliphatic carbon species as observed for the sample of lignite ash. Our results show that lignite of the parent substrate and lignite-derived ash may contribute mainly to the aliphatic and aromatic carbon of the lignite-containing mine soils.

${ }^{13} \mathrm{C}$ NMR CPMAS spectra of the organic layer and the mineral soil under 20-year-old Scots pine and the 36-year-old red oak are presented in Figs. 2 and 3. Spectra of the $\mathrm{Cv}$ horizon show chemical structures which resemble lignite. In the solid-state ${ }^{13} \mathrm{C}$ NMR spectra of the forest floor (L, Of, Oh) and Ai horizon of 


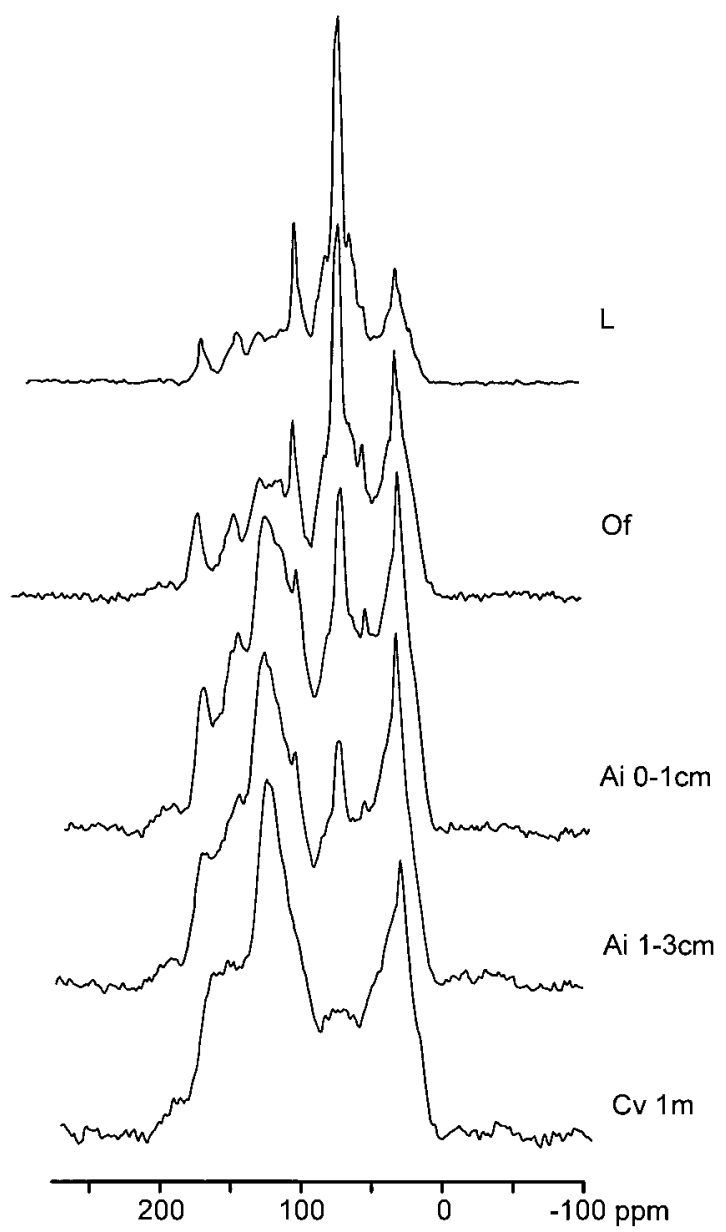

Fig. 2. ${ }^{13} \mathrm{C}$ CPMAS NMR spectra of the forest floor and the mineral soil sampled in the soil profile under 20-year-old Scots pine.

the two sites, additional peaks were identified, indicating the presence of organic matter originating from plant material. Indicative of those structures are the chemical shift region 50-110 ppm with the peak at $72 \mathrm{ppm}$, and a shoulder at $105 \mathrm{ppm}$, most probably assigned to carbohydrate structures. Signals at 119, 130, 150 and $56 \mathrm{ppm}$ may originate from lignin compounds and represent protonated, C-substituted, O-substituted aromatic $\mathrm{C}$ and methoxyl $\mathrm{C}$. The peak at $192 \mathrm{ppm}$ can be assigned to carbonyl groups. In the spectra of the Ai horizon, a decrease in signal intensity of polysaccharide and lignin carbon can be observed. A higher amount of aromatic and aliphatic carbon species contributes to these spectra.

Organic matter derived from plant material of the young mine soils represents an early stage of humification, consisting most probably mainly of plant litter 


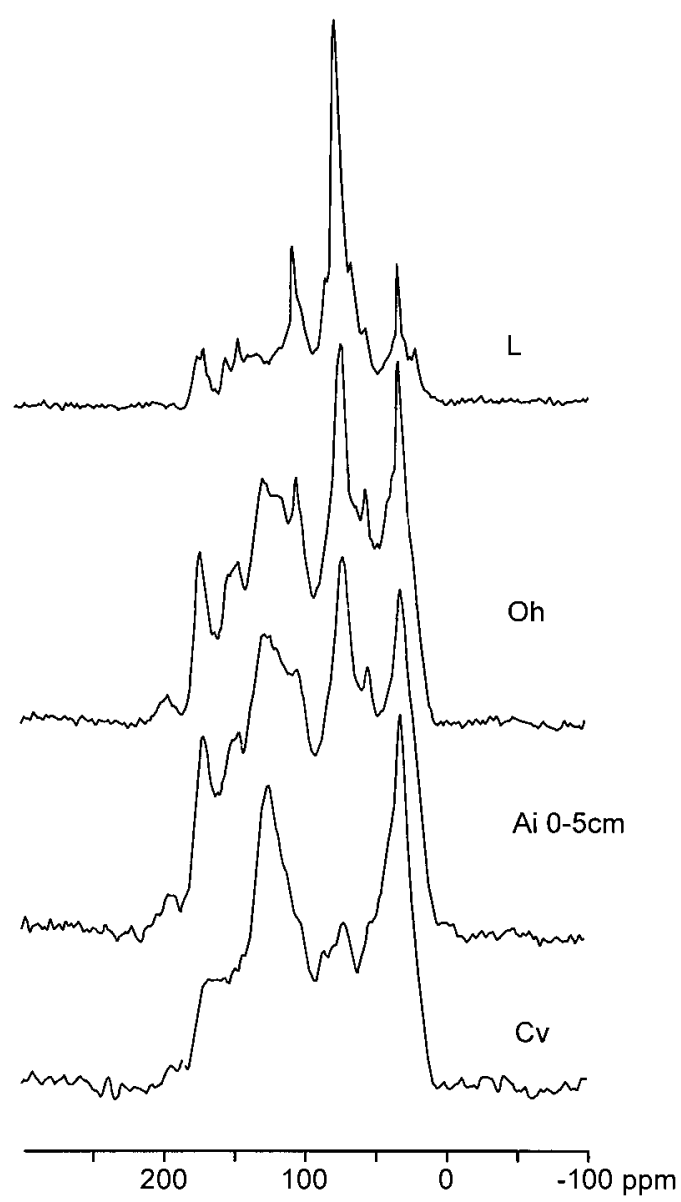

Fig. $3 .{ }^{13} \mathrm{C}$ CPMAS NMR spectra of the forest floor and the mineral soil sampled in the soil profile under 36-year-old red oak.

compounds. The NMR spectra of the Ai horizon of lignite-rich mine soils show clear evidence of plant litter compounds such as carbohydrate and lignin, which are related to pedogenesis. Polysaccharides and lignin were found to be major components of the organic matter in plant litter and forest floor material, as well as A horizons of forest soils (Kögel-Knabner, 1993; Baldock and Preston, 1995). During decomposition of plant material in forest soils, a decrease of O-alkyl carbon and an increase in the intensity of carboxylic C (175 ppm) and of the alkyl C signal (30 ppm) can be observed in ${ }^{13} \mathrm{C}$ CPMAS NMR spectra (Fründ et al., 1994; Knicker and Lüdemann, 1995). Plant derived polysaccharides are decomposed preferentially in comparison to alkyl and aromatic material (Haider, 1986) with concurrent increase of carbohydrates from microbial sources (Kögel-Knabner, 1993). In lignite-rich mine soils, the composition of the organic matter does hardly show the structural changes occurring during decom- 
position of plant litter. The ${ }^{13} \mathrm{C}$ NMR spectra of the Ai horizons are dominated by carbon species related to lignite. Those are aromatic and aliphatic carbon species, characteristic for organic matter which has been subject to the coalification process (Meiler and Meusinger, 1991; Hatcher et al., 1989; Wilson et al., 1987). Unusually high contribution to the aromatic component of the ${ }^{13} \mathrm{C}$ CPMAS NMR spectrum was noticed for the forest floor (Oh, Of horizon) (Figs. 2 and 3). This may be an indication of input of carbonaceous particles from ash that may have increased the contribution of aromatic carbon, represented by the $130 \mathrm{ppm}$ peak to the spectrum of forest floor horizons of the studied mine soils in comparison to natural sites.

The ratio of signal intensities [alkyl $\mathrm{C}+$ aromatic $\mathrm{C}] /[\mathrm{O}-$ alkyl + carboxylic C] can be used as an indicator for the presence of lignite in soils (Schmidt et al., 1996). For the two study sites, the integrals of the ${ }^{13} \mathrm{C}$ NMR spectra and ratios of signal intensity are given in Table 6. Integrals of the lignite samples are shown for comparison. Ratios of signal intensities for lignite samples were 1.4 and 1.5. Ratios of 1.7 in the $\mathrm{Cv}$ horizon of the 20 -year-old pine site indicate that SOM structure is dominated by lignite, whereas ratios of the forest floor horizons were observed to be well below 1. The ratio for the Ai horizon under 20-year-old pine (1.4 and 1.6) corresponds to the amount of lignite determined by ${ }^{14} \mathrm{C}$ activity measurements (69 to $83 \%$ ) (Tables 5 and 6 ). At the red oak site, ratios for Oh and Ai horizons, containing less lignite carbon (25 and 49\%) were somewhat lower (0.94 to 0.96 ). The spectrum of the $\mathrm{Cv}$ horizon dominated by lignite had a ratio of 1.4. These values are in agreement with the data recorded

Table 6

Integrals of ${ }^{13} \mathrm{C}$ CPMAS NMR spectra of bulk soils from the Ai horizon under 20-year-old Scots pine, from the $\mathrm{Ai}$ and $\mathrm{Oh}$ horizon under 36-year-old red oak and lignite samples (\% of signal intensity in chemical shift regions $-10-45 \mathrm{ppm}, 45-110 \mathrm{ppm}, 110-160 \mathrm{ppm}$ and 160-220 ppm)

\begin{tabular}{|c|c|c|c|c|c|}
\hline Horizon & Alkyl C & O-alkyl C & Aromatic C & Carboxylic C & $\begin{array}{l}\text { Alkyl + aromatic/ } \\
\text { O-alkyl + carboxylic }\end{array}$ \\
\hline
\end{tabular}

\section{Red oak}

$\begin{array}{llllll}\mathrm{L} & 14 & 61 & 19 & 6 & 0.48 \\ \mathrm{Oh} & 28 & 40 & 22 & 10 & 0.94 \\ \mathrm{Ai} & 28 & 36 & 24 & 12 & 0.96 \\ \mathrm{Cv}(<53 \mu \mathrm{m}) & 33 & 16 & 38 & 14 & 1.4\end{array}$

Scots pine

\begin{tabular}{llllll} 
L & 16 & 65 & 16 & 3 & 0.47 \\
Of & 24 & 48 & 22 & 6 & 0.85 \\
Ai1 $(0-1 \mathrm{~cm})$ & 20 & 33 & 39 & 8 & 1.4 \\
Ai2 $(1-3 \mathrm{~cm})$ & 20 & 29 & 41 & 10 & 1.6 \\
$\mathrm{Cv}(1 \mathrm{~m})$ & 18 & 24 & 46 & 12 & 1.7 \\
lignite 1 & 22 & 30 & 39 & 9 & 1.5 \\
lignite 2 & 32 & 25 & 27 & 16 & 1.4 \\
\hline
\end{tabular}


by Schmidt et al. (1996), who observed ratios for agricultural sites to be $<1$, whereas influence of contamination with brown coal emissions increased the ratio $>1$, and was 2.3 for pure brown coal.

The data obtained by ${ }^{13} \mathrm{C}$ NMR spectroscopy indicate that structural differentiation of lignite carbon and carbon originating from plant material is possible. The organic matter of lignite-rich mine soils consists of a mixture of carbon species related to plant material and carbon species related to lignite. Increasing lignite contribution in the mineral soil with depth can be observed by ${ }^{13} \mathrm{C}$ CPMAS NMR spectroscopy. Changes occurring during decomposition of plant litter are hardly noticeable.

\section{6. ${ }^{15}$ N NMR spectra}

Fig. 4 shows the ${ }^{15} \mathrm{~N}$ CPMAS-NMR spectra of the Ai horizon of the 20 -year-old pine site. They are dominated by a peak at $-257 \mathrm{ppm}$, representing amide structures that include peptides, acetylated amino sugars, and lactams (chemical shift region -220 to $-285 \mathrm{ppm}$ ). Similar spectra were obtained recently for agricultural soils (Knicker et al., 1993). Coalified materials produce ${ }^{15} \mathrm{~N}$ NMR spectra with the main signal in the chemical shift region between -120 and $-270 \mathrm{ppm}$ peaking at $-240 \mathrm{ppm}$. These signals are most likely assigned to pyrrolic, imidazolic and indolic N (Knicker et al., 1996). Even in spectra of lignite at very early stage of coalification, those signals are dominat-

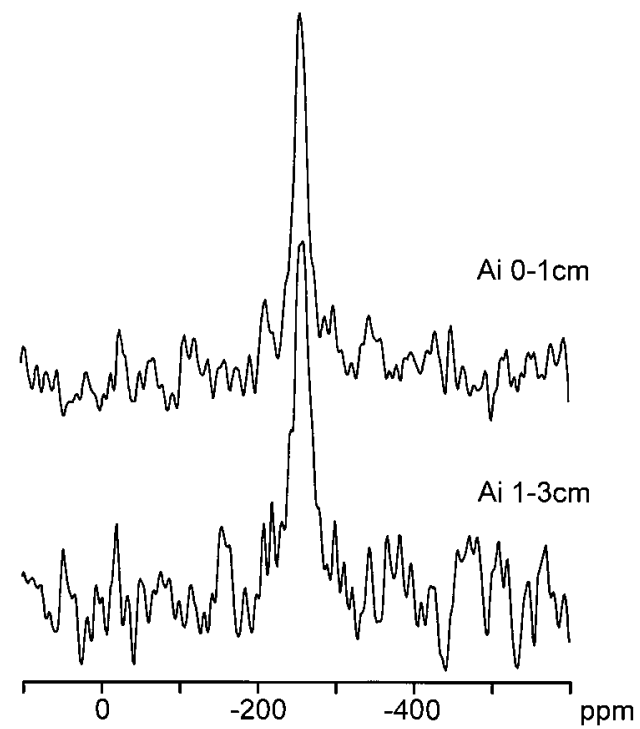

Fig. $4 .{ }^{15} \mathrm{~N}$ CPMAS NMR spectra of the Ai horizon $(0-1$ and $1-3 \mathrm{~cm})$ sampled in the soil profile under 20-year-old Scots pine. 
ing (Knicker, unpublished data). In the spectra presented here, signals in these regions cannot be identified because of the strong background noise.

Total nitrogen content of the lignite-rich mine soils is high in comparison to natural sites. It has been suggested that lignite is an important $\mathrm{N}$ source in spoils (Palmer et al., 1985). Microbial growth may have led to transformation of nitrogen structures in lignite to peptide-like structures. Another nitrogen source for micro-organisms especially in early stages of mine soil development may have been the readily available fertiliser. However, data of Reeder (1988) indicate that under field conditions, a large proportion of added fertiliser $\mathrm{NH}_{4}^{+}$is susceptible to loss via $\mathrm{NO}_{3}^{-}$leaching or volatilisation in spoils. Airborne contamination may also be an important nitrogen source at recultivated mine sites. In the lowlands of East Germany, nitrogen content in soil is increased by high amounts of airborne $\mathrm{N}$ especially in the vicinity of lignite-fired power stations and agricultural enterprises (Heinsdorf, 1993). Microbial growth may also rely on these $\mathrm{N}$ inputs. Our data show that organic nitrogen in the mine soil profile is mainly present in recently formed organic matter, most probably derived from peptide-like structures of biogenic origin.

\section{Conclusions}

The composition of organic matter of lignite-rich mine soils under forest has been studied at a red oak site and a Scots pine site using radiocarbon dating, ${ }^{13} \mathrm{C}$ and ${ }^{15} \mathrm{~N}$ CPMAS NMR spectroscopy and electron microscopy.

These techniques give evidence of four organic matter types related to decomposing plant material and lignite: (1) lignite inherent to the parent substrate for soil development; (2) organic matter derived from decomposition of plant residues; (3) carbonaceous particles in amelioration ash and (4) carbonaceous particles from airborne lignite-derived contamination.

Magnetic susceptibility measurements provide an indication of the presence of magnetic particles originating from lignite-derived combustion products. Because of its high carbon content, lignite-derived ash and lignite dust must be considered as carbon sources in lignite-rich mine soils.

Quantitative information on lignite $\mathrm{C}$ contribution can be obtained by radiocarbon dating. It was shown that after 36 years, more than half of the organic carbon in the Ai-horizon $(0-5 \mathrm{~cm})$ under red oak is derived from decomposing plant material. Lower contribution of recently formed organic matter in the Ai horizon of the 20-year-old pine site is explained by the higher age and the higher biological activity at the red oak site. Elucidation of structural differences of lignite $\mathrm{C}$ and $\mathrm{C}$ deriving from the decomposition of plant litter is possible by solid-state ${ }^{13} \mathrm{C}$ CPMAS NMR spectroscopy. Signals of plant material (polysaccharides and lignin structures) can be distinguished from the aliphatic and aromatic carbon species of lignite. It was shown that higher lignite contribution 
as determined by radiocarbon dating increases the ratio of (aromatic + aliphatic carbon) $/(\mathrm{O}$-alkyl + carboxylic carbon).

Structural information from ${ }^{13} \mathrm{C}$ and ${ }^{15} \mathrm{~N}$ CPMAS NMR spectroscopy indicate that carbon species of lignite are important contributors to the organic matter of the mine soils. $\mathrm{N}$ compounds seem to be present as peptide-like structures of biogenic origin.

\section{Acknowledgements}

We thank the Deutsche Forschungsgemeinschaft for financial support. H.-D. Lüdemann is acknowledged for support in obtaining the ${ }^{13} \mathrm{C} N M R$ and ${ }^{15} \mathrm{~N}$ NMR measurements P. Becker-Heidmann for the ${ }^{14} \mathrm{C}$ age determination. W. Wiehe of the central analytical laboratory of the Technical University of Cottbus is acknowledged for the scanning electron microscope photographs. We are grateful to Dr. Stanjek (Technische Universität München) for his help with the calibration of the magnetic susceptibility measurements. E. Schuhbauer (Technische Universität München) is acknowledged for preparing the figures. We thank the two reviewers G. Guggenberger and N. Senesi for valuable comments on the manuscript.

\section{References}

Baldock, J.A., Preston, C.M., 1995. Chemistry of carbon decomposition processes in forests as revealed by solid-state carbon-13 nuclear magnetic resonance. In: McFee, W.W., Kelly, J.M. (Eds.), Carbon Forms and Funktions in Forest Soils. Soil Science Society of America, Madison, pp. 89-118.

Bates, A.L., Hatcher, P.G., 1989. Solid-state ${ }^{13}$ C NMR studies of a large fossil gymnosperm form the Yallourn Open Cut, Latrobe Valley, Australia. Org. Geochem. 14, 609-617.

Becker-Heidmann, P., 1989. Die Tiefenfunktion der natürlichen Kohlenstoffisotopengehalte von vollständig dünnschichtweise beprobten Parabraunerden und ihre Relation zur Dynamik der organischen Substanz in diesen Böden. Hamburger Bodenkundl. Arbeiten 13, 1-225.

Becker-Heidmann, P., Liang-Wu, L., Scharpenseel, H.W., 1988. Radiocarbon dating of organic matter fractions of a Chinese mollisol. Z. Pflanzenernähr. Bodenk. 151, 37-39.

Beckwith, P.R., Ellis, J.B., Revitt, R.M., Oldfield, F., Thompson, R., 1986. Heavy metal and magnetic relationships for urban source sediments. Phys. Earth Planet. Inter. 42, 67-75.

Dearing, J.A., Lees, J.A., White, C., 1995. Mineral magnetic properties of acid gleyed soils under oak and Corsican Pine. Geoderma 68, 309-319.

Fründ, R., Guggenberger, G., Haider, K., Knicker, H., Kögel-Knabner, I., Lüdemann, H.-D., Luster, J., Zech, W., Spiteller, M., 1994. Recent advances in the spectroscopic characterization of soil humic substances and their ecological relevance. Z. Pflanzenernähr. Bodenk. 157, $175-186$.

Gil-Sotres, F., Trasar-Cepeda, M.C., Ciardi, C., Ceccanti, B., Leirós, M.C., 1992. Biochemical characterization of biological activity in very young mine soils. Soil Biol. Biochem. 13, 25-30.

Given, P.H., 1984. An essay on the organic geochemistry of coal. In: Gorbaty, M.L. et al. (Eds.), I. Coal Science, Vol. 3, Academic Press, New York, pp. 63-252. 
Goldberg, E.D., 1985. Black Carbon in the Environment. Properties and Distribution. Wiley-Interscience, New York.

Gonzales-Sanregorio, M.V., Trasar-Cepeda, M.C., Leiros, M.C., Gil-Sotres, F., Guitian-Ojea, F., 1991. Early stages of lignite mine soil genesis. Changes in biochemical properties. Soil Biol. Biochem. 23, 589-595.

Häge, K., 1996. Recultivation in the Lusatian mining region-targets and prospects. Water Air Soil Pollut. 91, 43-57.

Haider, K., 1986. The synthesis and degradation of humic substances in soil. Trans. Congr. Int. Soc. Soil Sci., 13th, 4, pp. 644-656.

Hatcher, P.G., 1988. Dipolar-dephasing ${ }^{13} \mathrm{C}$ NMR studies of decomposed wood and coalified xylem tissue: evidence for chemical structural changes associated with defunctionalization of lignin structural units during coalification. Energy Fuels 1, 40-58.

Hatcher, P.G., Wilson, M.A., Vasallo, A.M., Lerch, H.E., 1989. Studies of angiospermous woods in Australian brown coals by nuclear magnetic resonance and analytical pyrolysis: new insights into early coalification. Int. J. Coal Geol. 13, 99-126.

Haumeier, L., Zech, W., 1995. Black carbon-possible source of highly aromatic compounds of soil humic acids. Org. Geochem. 23, 191-196.

Heinsdorf, D., 1993. The role of nitrogen in declining Scots pine forests (Pinus sylvestris) in the lowland of East Germany. Water Air Soil Pollut. 69, 21-35.

Katzur, J., Haubold-Rosar, M., 1996. Amelioration and reforestation of sulfurous mine soils in Lusatia (Eastern Germany). Water Air Soil Pollut. 91, 17-32.

Knicker, H., 1993. Quantitative 15N- und 13C-CPMAS-Festkörper- und 15N-Flüssigkeits-NMR Spektroskopie an Pflanzenkomposten und natürlichen Böden. Dissertation.

Knicker, H., Lüdemann, H.-D., 1995. N-15 and C-13 CPMAS and solution NMR studies of N-15 enriched plant material during 600 days of microbial degradation. Org. Geochem. 23, 329-341.

Knicker, H., Nanny, M.A., 1997. Nuclear magnetic resonance spectroscopy basic theory and background. In: Nanny, M.A. et al. (Eds.) Nuclear Magnetic Resonance Spectroscopy in Environmental Chemistry, Oxford Univ. Press, London, pp. 3-18.

Knicker, H., Fründ, R., Lüdemann, H.-D., 1993. The chemical nature of nitrogen in soil organic matter. Naturwissenschaften 80, 219-221.

Knicker, H., Almendros, G., Gonzalez-Vila, F.J., Lüdemann, H.-D., Martin, F., 1995. 13C and $15 \mathrm{~N}$ NMR analysis of some fungal melanins in comparison with other bio- and geo-macromolecules. Org. Geochem. 23, 1053-1060.

Knicker, H., Hatcher, P.G., Scaroni, A.W., 1996. A solid-state 15N NMR spectroscopic investigation of the origin of nitrogen structures in coal. Int. J. Coal Geol. 32, 255-278.

Kögel-Knabner, I., 1993. Biodegradation and humification processes in forest soils. In: Bollag, J.-M., Stotzky, G. (Eds.), Soil Biochemistry. Marcel Dekker, New York, 8, pp. 101-137.

Libby, W.F., 1969. BI-Taschenbuch, Berlin.

Locke, G., Bertine, K.K., 1986. Magnetite in sediments as and indicator of coal combustion. Appl. Geochem. 1, 345-356.

Meiler, W., Meusinger, R., 1991. NMR of coals and coal products. Annu. Rep. NMR Spectrosc. 23, 376-410.

Packer, K.J., Harris, R.K., Kenwright, A.M., Snape, C.E., 1983. Quantitative aspects of solid state 13C n.m.r. of coals and related materials. Fuel 62, 999-1002.

Palmer, J.P., Morgan, A.L., Williams, P.J., 1985. Determination of the nitrogen composition of colliery spoil. J. Soil Sci. 36, 209-217.

Querol, X., Pares, J.M., Plana, F., Fernandezturiel, J.L., 1993. Fly ash content and distribution in lake sediments around a large power station: interferences from magnetic susceptibility analysis. Environ. Geochem. Health 15, 9-18.

Raask, E., 1984. Creation, capture and coalescence of mineral species in coal flames. J. Inst. Energy 57, 231-239. 
Reeder, J.D., 1988. Transformation of nitrogen-15-labeled fertilizer nitrogen and carbon mineralization in incubated coal mine spoils and disturbed soil. J. Environ. Qual. 17, 291-298.

Roberts, J.A., Daniels, W.L., Bells, J.C., Burger, J.A., 1988. Early stages of mine soil genesis in a southwest Virginia spoil lithosequence. Soil Sci. Soc. Am. J. 52, 716-723.

Rose, N.L., 1996. Inorganic fly-ash spheres as pollution tracers. Environ. Pollut. 91, 245-252.

Rumpel, C., Knicker, H., Kögel-Knabner, I., Hüttl, R.F., 1998. Airborne contamination of forest soils by lignite derived materials: its detection and its impact on the composition of organic matter in soils. Water, Air, Soil Pollut., in press.

Schädlich, G., Weißflog, L., Schürmann, G., 1995. Magnetic susceptibility in conifer needles as indicator of fly ash deposition. Fresenius Environ. Bull. 4, 7-12.

Schaefer, J., Stejskal, E.O., 1976. Carbon-13 nuclear magnetic resonance of polymers spinning at magic angle. J. Am. Chem. Soc. 98, 1031-1032.

Smith, K.L., Smooth, C., Fletcher, T.H., 1993. Coal characteristics, structure, and reaction rates. In: Smooth, L.D. (Ed.) Fundamentals of Coal Combustion. Elsevier, Amsterdam, pp. 131-293.

Schmidt, M.W.I., Knicker, H., Hatcher, P.G., Kögel-Knabner, I., 1996. Impact of brown coal dust on a soil and its size fractions-chemical and spectroscopic studies. Org. Geochem. 25, 29-39.

Schmidt, M.W.I., Knicker, H., Hatcher, P.G., Kögel-Knabner, I., 1997. Improvement of 13C and 15CPMAS NMR spectra of bulk soils, particle size fractions and organic material by treatment with hydrofluoric acid (10\%). Eur. J. Soil Sci. 48, 319-328.

Schmidt, M.W.I., Rumpel, C., Kögel-Knabner, I., 1998. Standardization of ultrasonic dispersion energy to isolate primary organomineral complexes from natural and anthropogenic soils. Eur. J. Soil Sci., submitted.

Skjemstad, J.O., Clarke, P., Golchin, A., Oades, J.M., 1997. Characterization of soil organic matter by solid-state ${ }^{13} \mathrm{C}$ NMR spectroscopy. In: Cadisch, G., Giller, K.E. (Eds.), Driven by Nature: Plant Litter Quality and Decomposition. CAB International, pp. 253-271.

Snape, C.E., Axelson, D.E., Botto, R.E., Delpuech, J.J., Tekely, P., Gerstein, B.C., Pruski, M., Maciel, G.E., Wilson, M.A., 1989. Quantitative reliability of aromaticity and related measurements on coals by 13C NMR. A debate. Fuel 68, 547-560.

Stach E., Mackowsky M.-T., Teichmüller M., Taylor, G.H., Chandra, D., Teichmüller, R., 1982. Stach's Textbook of Coal Petrology. Gebrüder Borntraeger, Berlin.

Strzyszcz, Z., 1993. Magnetic Susceptibility of soils in the areas influenced by industrial emissions. In: Schulin, R. et al. (Eds.), Soil Monitoring. Early Detection and Surveying of Soil Contamination and Degradation. Birkenhäuser, pp. 255-269.

Stuiver, M., Polach, H.A., 1977. Discussion: reporting of 14C data. Radiocarbon 19, 355-363.

Wilson, M.A., Verheyen, T. V, Vassallo, A.M., Hill, R.S., Perry, G.J., 1987. Selective loss of carbohydrates from plant remains during coalification. Org. Geochem. 11, 265-271.

Wilson, M.A., 1987. NMR-Techniques and Application in Geochemistry and Soil Chemistry. Pergamon, Oxford. 